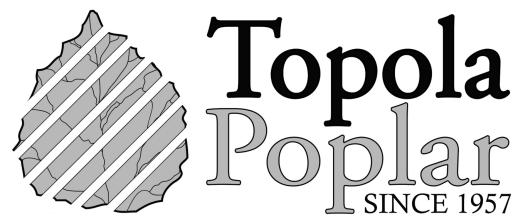

OPEN ACCESS

DOI: $10.5937 /$ topola2006029S

UDC: 595.78:582.634.2(497.11)"2019/2020"

Preliminary report

\title{
Choreutis nemorana (Hübner, 1799) (Lepidoptera: Choreutidae) in Serbia
}

\author{
Dejan V. Stojanović1 ${ }^{*}$, Dušanka Jerinić-Prodanovićc ${ }^{2}$ Tatjana Kereší3, Draga Graora², Miroslav \\ Marković $^{1}$
}

1 University of Novi Sad, Institute of Lowland Forestry and Environment, Novi Sad, Serbia

2 University of Belgrade, Faculty of Agriculture, Belgrade-Zemun, Serbia

3 University of Novi Sad, Faculty of Agriculture, Novi Sad, Serbia

* Corresponding author: Dejan V. Stojanović; E-mail: dejanstojanovic021@yahoo.co.uk

Received: 10 Nov 2020; Revised: 24 Nov 2020; Accepted: 11 Dec 2020

\begin{abstract}
Choreutis nemorana (Hübner, 1799), the fig-tree skeletonizer moth, is a widespread species in the Mediterranean region, which has rapidly expanded its distribution area northwards and eastwards during the last 15 years. This paper reports the localities in Serbia where the C. nemorana was recorded during 2019-2020, literature data and own observations on its developmental stages, morphological characteristics, biology and symptoms of damage in the figs.
\end{abstract}

Keywords: Choreutis nemorana, distribution, morphology, biology, harmfulness.

\section{Introduction}

Choreutis nemorana (Hübner, 1799) (Lepidoptera: Choreutidae), the fig-tree sceletonizer moth, fig leaf roller or fig moth, is also found in the literature under the names Tortrix nemorana Hübner, [1799], Asopia incisalis Treitschke, 1829, Simaethis nemorana Hübner, [1799], Choreutis incisalis and others.

Climate changes and global trade have caused huge modifications in the environment worldwide and thus provided great opportunities for invasive and other species to occupy new territories. These changes have most likely impacted on the spreading of $C$. nemorana. Over the last 15 years, this adventive pest has spread rapidly from its original Mediterranean area northwards and eastwards (Christian et al., 2008; De Prins et al., 2014; De Prins and De Prins, 2014; Fazekas, 2015; Todorova Vaneva-Gancheva, 2017).

During the last 30 years, we are witnesses that an increasing number of Mediterranean plants have managed to survive low winter temperatures in Serbia. Thus, rosemary, Persian silk tree, lavender, and especially figs (as a decorative, but also as a fruit species) are increasingly grown in our backyards in both, rural and urban areas. Insects that feed on these plants follow them by natural spread (flight, wind) or by another way (transportation of people and goods, especially ornamentals). Probably a similar pattern is present in C. nemorana, as well as in other Mediterranean insect species, already registered in Serbia, such as the fig psylla Homotoma ficus L. (Jerinić-Prodanović, 2011), the green vegetable bug Nezara viridula L. (Kereši et al., 2012), the cypress jewel beetle Lamprodila (Palmar) festiva L. (Kereši, 2020), stink bug Acrosternum heegeri Fieber, 1861 (Kereši and Konjević, 2020) and others. 
The aims of this study are to report about findings of C. nemorana in Serbia, lists the sites in country where it was observed during the 2019 and 2020 years and provide an additional description of the species and the symptoms of damage to the fig leaves.

\section{Material and methods}

This research was conducted in 2019 and 2020. Several standard methods for collecting specimens and monitoring of moths were used. Damaged plant parts (leaves and twigs) and the preimaginal stages (eggs, larvae of different ages and pupae) of fig-tree skeletonizer moth were collected, packaged and brought to the laboratory for further analysis, determination and photographing. Adults were grown in the laboratory or collected using the entomological net. The collected adults were afterwards stored as dry specimens in entomological boxes in the private collection of the first author.

Permanent slides of the genital structures are deposited in the collection of permanent slides of the first author as well. For the purpose of proper identification, the copulatory organs of adult males and females were dissected and subsequently boiled in a water bath. Finally, the permanent microscope slides were made.

The most important morphological features of the specimens were photographed by a special digital photo accessory on a Carl Zeiss Stemi 2000 stereomicroscope. Photographs were processed using Motic $®$ image stacking software. Based on summarizing the localities where the species was recorded or caught, a precise $10 \times 10 \mathrm{~km}$ UTM map of the C. nemorana distribution in Serbia was constructed.

\section{Results and discussion}

\subsection{Distribution}

The fig-tree skeletonizer moth is a widespread species, present almost everywhere where figs (Ficus carica) are grown. It is common in the Mediterranean, from the Canary Islands, Madeira and northwestern Africa, in the west, to Asia Minor, Iran, the Caucasus, Georgia, Azerbaijan, Armenia and Uzbekistan in the east. It has been observed in Albania, Austria, Bosnia and Herzegovina, Bulgaria, Croatia, France, Germany, Greece, Hungary, Italy, Cyprus, Malta, Northern Macedonia, Portugal, Romania, Spain, Switzerland, Turkey and Ukraine (De Prins et al. 2014; Karsholt and van Nieukerken, 2013).

In our research, damage caused by the fig-tree skeletonizer moth in Serbia was for the first time observed in the summer of 2019 on the territory of Belgrade (Ledine DQ56) and Novi Sad (Sremski Karlovci DR10). After these findings, in 2020, the species was recorded at other locations in Belgrade (Zemun DQ56, Zeleni Venac DQ56, Voždovac DQ55), then in Vinča (DQ65), Gornja Bukovica (Valjevo DQ01), Ilinci (Šid CQ59), Čortanovci (DR20), Čerević (CR90), Ledinci (DR00), Rakovac (DR00), Beočin (DR00), Paragovo (DR00), Bukovac (DR10), Sremska Kamenica (DR00), Futog (CR91) and Rumenka (DR01).

According to our data (Figure 1), the fig-tree skeletonized moth is mostly distributed in northern Serbia and around Belgrade, but it can be expected that the species is present in other parts of country, too. Since 2005, the species began to spread northwards and eastwards in Europe, to countries where the fig is grown as an ornamental plant. According to Todorov Vaneva-Gancheva (2017), the first such northern finding was recorded in Austria (2004), followed by Germany (2006), Switzerland (2008), Belgium (2009) and Hungary (2012), while the latest data on the findings of the species are from Britain and the Netherlands (2014), Slovakia (2015) and Bulgaria (2016). 


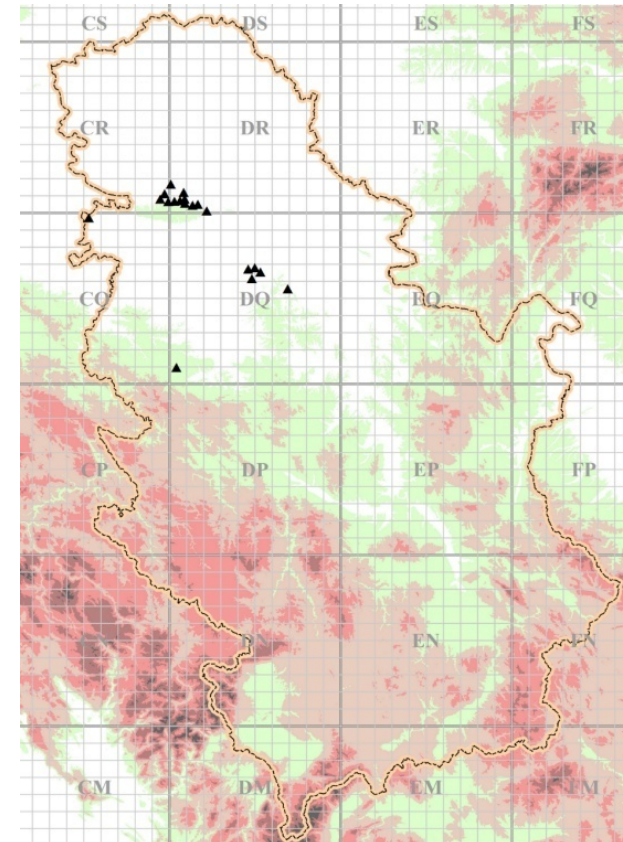

Figure 1. Map of localities in Serbia (2019-2020) with UTM grids Choreutis nemorana (Hübner, 1799).
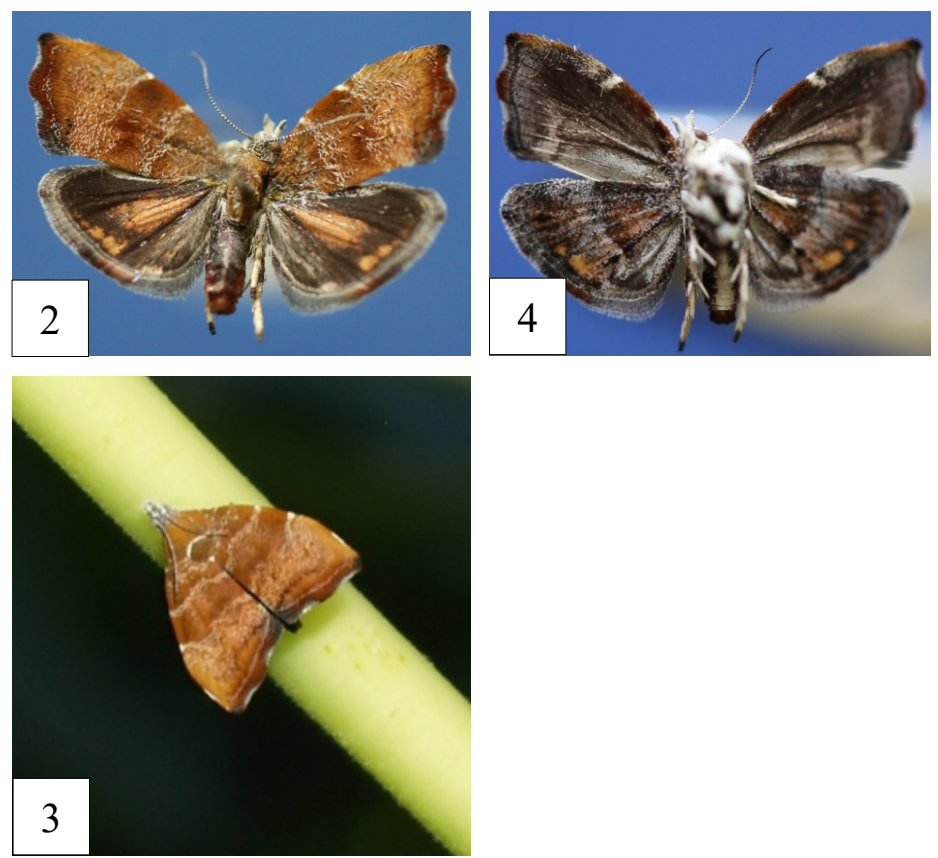

Figures 2-4. Choreutis nemorana, habitus of adults: 2 - with spread wings (dorsal view); 3 - with folded wings; 4 - with spread wings (ventral view) (Photo: D. V. Stojanović)

\subsection{Morphological description and biology}

Adults of the fig-tree skeletonizer moth have a wing span between 16 and $20 \mathrm{~mm}$. The color of the body is brown dorsally and light gray on the ventral side. The forewings are almost trapezoidal in shape with a wavy edge (Figure 2), orange-brown to dark brown in color with wavy silvery-gray transverse stripes, which give a characteristic pattern when the wings are folded (Figure 3). The hind wings are dark brown, with orange parts in the middle. From the ventral side, both pairs of wings are gray-brown (Figure 4). The eggs are spherical, whitish-creamy, $0.5 \mathrm{~mm}$ in diameter. The fully grown caterpillar is about $15-20 \mathrm{~mm}$ long, light green, shiny, semi-transparent, with a yellowish-brown head. On its dorsal side, there is a light longitudinal stripe in the middle of the body, and numerous black verrucae present on the thoracic and abdominal tergites (Figure 5). The pupa is dark brown, 7-8 mm long (Figure 6).
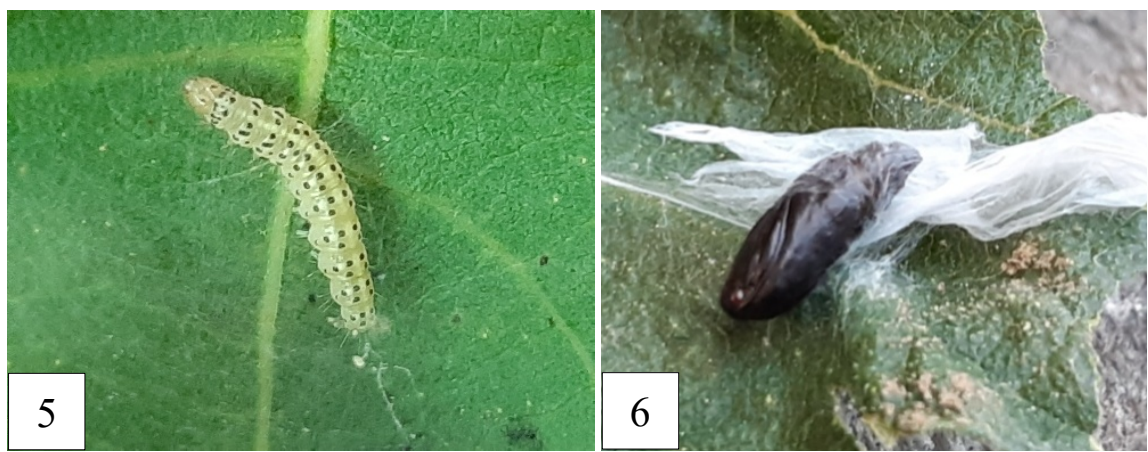

Figures 5 and 6. Choreutis nemorana: 5 - fully grown caterpillar; 6 - pupa.

(Photo: D. Jerinić-Prodanović and T. Kereši)

Male genitalia of Choreutis nemorana (Figure 7): Cucullus rounded on the peak, with a characteristic, finger-shaped curved Sacculuss from the anal side. Uncus tubular, narrowed towards 
the top. Female genitalia of Choreutis nemorana (Figure 8): Singum serrated, trapezoidal, within Corpus bursae.
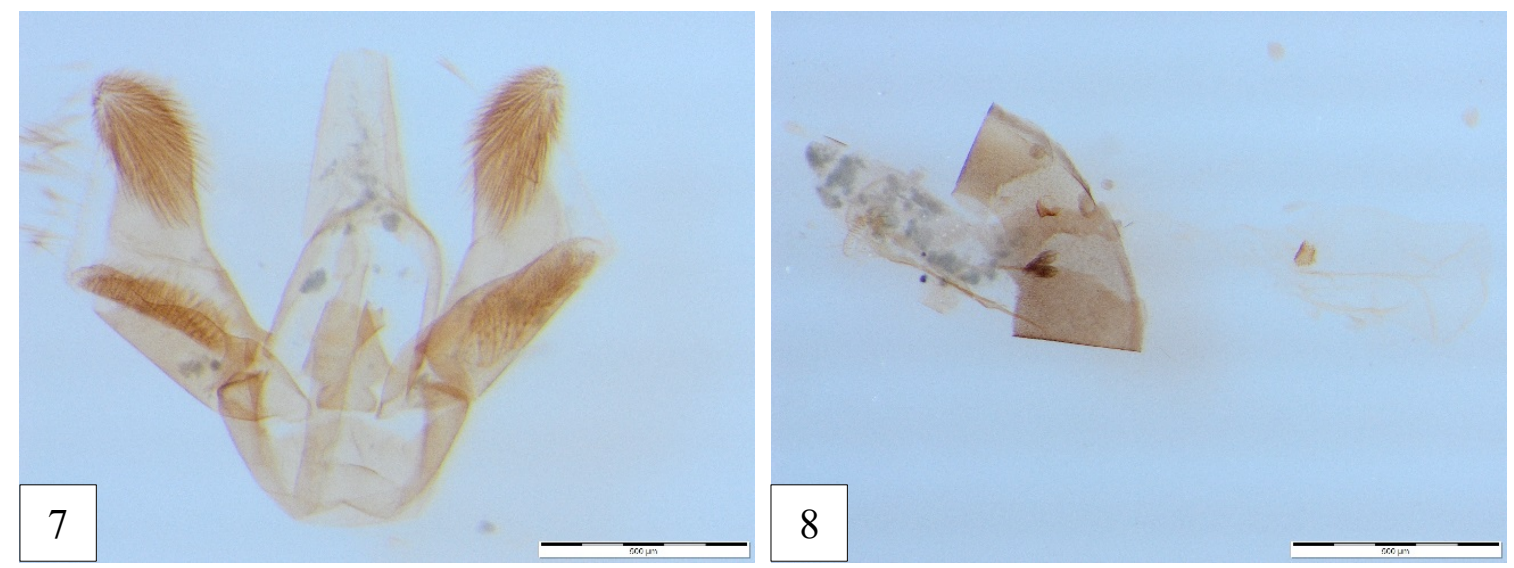

Figures 7 and 8. Choreutis nemorana: 7 - male genitalia; 8 - female genitalia. (Photo: D. V. Stojanović)

In 2020, on the outskirts of Sremski Karlovci (northern Serbia), on the same fig plant as in the previous year, due to a very early and warm spring, first damaged leaves were observed on May $31^{\text {th }}$ (Figure 9), together with a few caterpillars and one pupa of fig-tree skeletonizer moth on them. An adult was raised from the pupa on June 6, , in order to confirm the identification. Further development of the species was not monitored, because the plant was severely pruned and many branches were removed. At the beginning of September 2020, on the same tree, a significant damage was observed on the remaining branches (Figure 10), while on September 18, a several caterpillars of different ages under the silky cobweb were recorded on the fig shoots (Figure 11).
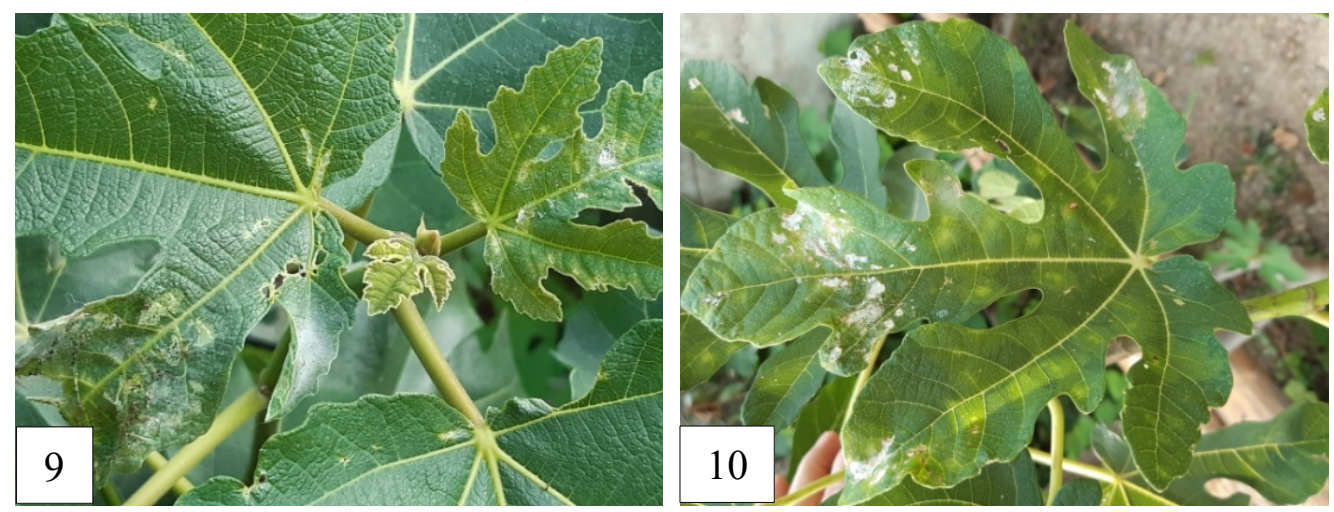

Figures 9 and 10. C. nemorana: 9 - damage on young leaves; 10 - damage on older fig leaves. (Photo: T. Kereši)

Depending on the altitude, the area where the species is found and the prevailing weather conditions, Choreutis nemorana can have one generation per year (Lendel, 2017), but most often it has two (Maceljski, 2002) or more generations per year. Its adult overwinters in hidden places. Overwintered individuals appear in early spring and females lay eggs on the face of fig leaves. The larvae feed on the softer parts of the leaves between the nerves and live protected for a few weeks under a sparsely defined, transparent silky threads. The summer-generation adults usually eclode during July and August, while the second-generation of moths occurs in fall (September-October) and overwinters in plant debris and other hidden places (Alford, 2007; Christian et al. 2008; De Prins et al. 2014; Fazekas, 2015; Todorova Vaneva-Gancheva, 2017). 

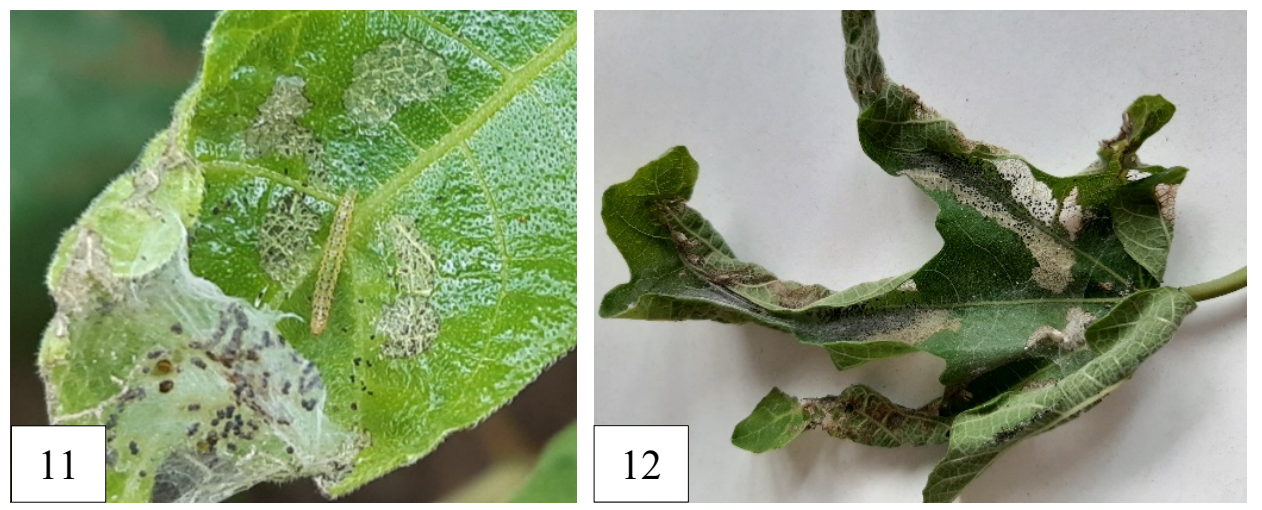

Figures 11 and 12. C. nemorana: 11 - caterpillar under silky threads; 12 - severe damaged leaf. (Photo: T. Kereši and D. Jerinić-Prodanović)

\subsection{Harmfulness}

Damage is caused by larvae, which at younger ages gnaw the upper parenchymal cells of younger leaves, leaving the lower parts of the leaves intact (Figure 11). Older caterpillar feed on both the upper and lower parenchymal cells, leaving the leaf nerves intact, causing the symptom of skeletonized leaves. During feeding, they often fold the top of leaves and feed inside that shelter. As a consequence of damage, the leaves are twisted and discolored, scarring and cracking occur (Figure 12) and leaves look shabby or even fall off. Grown larvae pupate in a white silk cocoon on the upper side of fig leaf, under the bent tip of leaf or on the other parts of the plants.

In Croatia, this moth is a regular pest of figs, but it rarely appears in significant numbers to cause more economically serious damage, and therefore chemical protection is not applied (Maceljski, 2002). Control measures are performed by removing and destroying the infested leaves at the time when the caterpillars are on them. The fig-tree skeletonizer moth causes more serious damage only when it appears in large numbers on a one tree. Since it weakens the lushness of fig shoots, preconditions are created for the attack of bark beetles. It can be controlled with insecticides used against fig psylla, although the obvious lack of plant protection products registered for figs is present. The natural enemies of fig-tree skeletonizer moth are tachinids, parasitic bugs and parasitic wasps (Grbić-Atelj, 2019).

The fig-tree skeletonizer moth is a monophagous species that feeds exclusively on fig leaves (Mifsud et al. 2012). It belongs to the minor, less significant pests of figs, primarily attacks solitary trees and is less common in fig plantations (Alford, 2007). Contrary to the latter claim, sometimes the fig-tree skeletonizer moth can cause significant damage in orchards, as evidenced in Tunisia (Zouba, 2010) and Iran (Chitgar et al. 2014). During the mass appearance of the species, when almost every fig leaf is attacked, the second generation caterpillars can also damage the fruits.

\section{Conclusions}

With these findings, Serbian fauna is enriched with one species of the family Choreutidae, which is potentially harmful to figs.

\section{Acknowledgment}

This study was financed by the Ministry of Education, Science and Technological Development of the Republic of Serbia (Contract No. 451-03-68/2020-14/200197). 


\section{References}

1. Alford, D.V. (2007): Pest of fruit crops: a color handbook. Manson publishing, London, $461 \mathrm{pp}$.

2. Chitgar, M. G., Ghadamyari, M., Sharifi, M., Sajedi, R. H. (2014): Partial characterization of digestive carbohydrases in the midgut of fig tree sceletonizer moth, Choreutis nemorana (Hübner, 1799) (Lepidoptera: Choreutidae). Trakia J. of Sciences 12(1): 27-37.

3. Christian, E., Deutsch, H., Huemer, P. (2008): The fig-tree skeletonizer moth Choreutis nemorana (Hübner, 1799) gains ground in Austria (Lepidoptera: Choreutidae). Beiträge zur Entomofaunistik 9: 178-180.

4. De Prins, W., Baugnée, J.-Y., Georis, A., Spronck, R., Spronck, R. (2014): Choreutis nemorana (Hübner, 1799) (Lepidoptera: Choreutidae) well established in Belgium. Phegea 42(2): 29-32.

5. De Prins, W., De Prins, J. (2014): Choreutis nemorana (Hübner, 1799) (Lep.: Choreutidae), a new adventives species to the British Isles. Entomologist's Rec. J. Var. 126: 157-163.

6. Fazekas I. (2015): Choreutis nemorana (Hübner, 1799) an adventives species in Hungary. Microlepidoptera.hu: 3-10.

7. Grbić-Atelj, S. (2019): Problemi u zaštiti smokve na području zadarske županije tijekom vegetacije 2018. godine. Glasilo biljne zaštite 19(4): 469-480.

8. Jerinić-Prodanović, D. (2011): The first finding of the fig psylla Homotoma ficus L. (Hemiptera, Psylloidea, Homotomidae) in Serbia. Pesticidi i fitomedicina 26(3): 205-212.

9. Karsholt, O., van Nieukerken, E.J. (2013) Lepidoptera, Moths. Fauna Europaea version 2017.06, https://fauna-eu.org

10. Kereši, T. (2020): Recent records of the cypress jewel beetle - Lamprodila (Palmar) festiva (Linnaeus, 1767) (Coleoptera: Buprestidae) in Serbia. Topola/Poplar 205: 25-31.

11. Kereši, T., Konjević, A. (2020): Pojava dve manje poznate mediteranske vrste insekata u Srbiji. Biljni lekar 48(2): 7-20.

12. Kereši, T., Sekulić, R., Protić, Lj., Milovac, Ž. (2012): Pojava stenice Nezara viridula L. (Heteroptera: Pentatomidae) u Srbiji. Biljni lekar 40(4): 296-304.

13. Lendel, A. (2017): Choreutis nemorana (Hübner, 1799) a Gracillaria loriolella (Frey, 1881) - dva nové druhy motýl'ov pre faunu Slovenska. Folia faunistica Slovaca, 22: 1-5.

14. Maceljski, M. (2002): Poljoprivredna entomologija. Znanstveno popularna djela, knjiga 49, Zrinski, Čakovec. 519 pp.

15. Mifsud, I. D., Falzon, A., Malumphy, C., de Lillo, E., N. Vovlas, Porcelli, F. (2012): On some arthropods associated with Ficus species (Moraceae) in the Maltese Islands. Bulletin of the Entomological Society of Malta, 5: 5-34.

16. Vaneva-Gancheva, T.T. (2017): Choreutis nemorana (Hübner, 1799) (Lepidoptera: Choreutidae) - first record in Bulgaria. Silva Balcanica, 18(2): 43-47.

17. Zouba, A. (2010): First report of Choreutis nemorana (Hübner, 1799) (Lepidoptera: Choreutidae) in Tunisia. The African J. of Plant Science and Biotechnology 4(2): 96-97. 